KerRIDGe, D. (1959). J. gen. Microbiol. 21, 168-179

\title{
Synthesis of Flagella by Amino Acid-Requiring Mutants of Salmonella typhimurium
}

\author{
BY D. KERRIDGE* \\ The Guinness-Lister Microbiology Unit, The Lister Institute of Preventive \\ Medicine, Chelsea Bridge Road, London S.W. 1
}

\begin{abstract}
SUMMARY: Amino acid-requiring mutants of Salmonella typhimurium were examined for their ability to regenerate flagella when incubated with a source of nitrogen and of energy, but in the absence of the amino acid required for growth. The mutants fell into two major groups and one intermediate group. The major groups were: (a) mutants requiring for growth an amino acid (such as leucine or tyrosine) present in flagellin and unable to regenerate flagella in the absence of this amino acid. (b) mutants requiring for growth an amino acid (such as tryptophan or cysteine) not present in flagellin and able to regenerate flagella in the absence of this amino acid. The intermediate group (c) contained mutants requiring for growth an amino acid (such as histidine or methionine) present in small amount in flagellin and able to regenerate flagella in the absence of this amino acid. With all the mutants tested there was no significant net synthesis of RNA or protein in the absence of the amino acid required for growth, but DNA synthesis did occur.
\end{abstract}

Bacterial flagella, unlike those of protozoa and algae, consist only of protein. Weibull (1953) and Rinker, Kobayashi \& Koffler (1957) showed that flagellar protein (flagellin) from Proteus vulgaris was homogeneous, had an approximate molecular weight of 17,000 , possessed an $N$-terminal alanine and was unusual in containing no tryptophan, histidine, proline or hydroxyproline. It differs from flagellin of Salmonella typhimurium which lacks tryptophan, cysteine and hydroxyproline (Mr R. P. Ambler and Mr M. W. Rees, Department of Biochemistry, Cambridge, personal communication). The $\mathbf{M}$ protein of group $\mathbf{A}$ haemolytic streptococci is similar to flagellin in being an incomplete protein, for it contains little or no aromatic amino acids. It is possible to remove the $M$ protein from the streptococci by trypsin digestion; the trypsin-treated organisms require amino acids, polypeptides and glucose for the synthesis of the $M$ protein; tryptophan and phenylalanine are essential for growth but not for synthesis of M protein in a chemically-defined medium (Fox \& Krampitz, 1956).

Stocker (1957) showed that flagella could be removed mechanically from Salmonella typhimurium without affecting the viability of the organisms and that in a nutrient broth these organisms were capable of regenerating their flagella. As bacterial flagella consist only of protein, regenerating flagella appeared to be a suitable system for studying by morphological and functional tests the factors which affect the synthesis of a single protein. In the present work the ability of amino acid-requiring mutants of Salmonella typhimurium

\footnotetext{
* Present address : M.R.C. Unit for Chemical Microbiology, Department of Biochemistry, Tennis Court Road, Cambridge.
} 
to regenerate flagella in the presence and absence of their amino acid growth requirements was investigated and compared with other synthetic abilities under the same conditions.

\section{METHODS}

\section{Organisms and growth media}

The mutant strains of Salmonella typhimurium used are detailed in Table 1. The cultures were maintained on Dorset egg slopes which were kept at room temperature.

For the preparation of washed suspensions, organisms were grown in nutrient broth made from a tryptic digest of horse meat; $50 \mathrm{ml}$. broth was inoculated with $1 \mathrm{ml}$. of an overnight culture and incubated aerobically without shaking for $4 \mathrm{hr}$. at $37^{\circ}$; the organisms were at the end of the logarithmic phase of growth after this period. The organisms were harvested by centrifugation, washed twice with $0.01 \mathrm{M}$-phosphate buffer $(\mathrm{pH} 7 \cdot 0$ ) and resuspended in the same buffer at a concentration equiv. $10 \mathrm{mg}$. dry wt./ml. Starved preparations of the amino acid-requiring mutants were obtained by resuspending the washed organisms at a concentration equiv. to $1 \mathrm{mg}$. dry wt./ml. in a minimal

Table 1. Strains of Salmonella typhimurium used which require certain amino acids for growth

\begin{tabular}{|c|c|c|c|c|}
\hline Strain no. & $\begin{array}{l}\text { Parent } \\
\text { strain }\end{array}$ & $\begin{array}{l}\text { Growth } \\
\text { requirement }\end{array}$ & Lab. ref. no. & Source \\
\hline LT 2 & - & 一 & LT2 & $\begin{array}{c}\text { Zinder \& Leder- } \\
\text { berg (1952) }\end{array}$ \\
\hline 462 & 533 & Tyrosine & SL 185 & Dr M. H. Plough \\
\hline $480 M$ & 533 & Leucine & SL 186 & Dr M. H. Plough \\
\hline meA-6 & LT2 & Methionine & SL 262 & \\
\hline $\operatorname{try} A-8$ & LT2 & Tryptophan & SL282 & \\
\hline hiA-6 & LT2 & Histidine & SL 286 & \\
\hline hiB-20 & LT2 & Histidine & SL 287 & \\
\hline hiC-15 & LT2 & Histidine & SL 288 & Demerec et al. \\
\hline hiD-10 & LT2 & Histidine & SL 289 & (1956) \\
\hline cys 1 & LT2 & Cysteine & SL 291 & \\
\hline glu 1 & LT2 & Glutamic acid & SL 443 & \\
\hline
\end{tabular}

medium consisting of ( $\%$, w/v) $\mathrm{K}_{2} \mathrm{HPO}_{4}, 0 \cdot 7 ; \mathrm{KH}_{2} \mathrm{PO}_{4}, 0 \cdot 2 ; \mathrm{Na}_{3}$ (citrate) $.5 \mathrm{H}_{2} \mathrm{O}$, $0.05 ; \mathrm{MgSO}_{4} .7 \mathrm{H}_{2} \mathrm{O}, 0.01 ;\left(\mathrm{NH}_{4}\right)_{2} \mathrm{SO}_{4}, 0.1$; glucose, 0.2 . After aerobic incubation for $30 \mathrm{~min}$. at $37^{\circ}$ the organisms were harvested by centrifugation, washed and resuspended in buffer as before.

The dry weights of the organisms in suspension were determined from optical density measurements at $420 \mathrm{~m} \mu$ by using a Unicam SP 500 spectrophotometer and a calibration curve for the organisms prepared by drying samples of known optical density to constant weight at $105^{\circ}$.

The flagella were detached mechanically from the bacteria. Ten $\mathrm{ml}$. of the bacterial suspension in buffer was placed in a $25 \mathrm{ml}$. masticator (MSE 77313) and blended at room temperature by a MSE microhomogenizer. One to $2 \mathrm{~min}$. blending at $12,000 \mathrm{rev}$. $/ \mathrm{min}$. was sufficient to decrease the number of flagellated bacteria to $<1 \%$ of the total. 


\section{Regeneration of bacterial flagella}

Regeneration of flagella was carried out in $250 \mathrm{ml}$. conical flasks containing phosphate buffer ( $\mathrm{pH} 7 \cdot 0$; final concentration $0.01 \mathrm{M}$ ), glucose $0.2 \%(\mathrm{w} / \mathrm{v})$ and the following amino acids each in a concentration of $0.1 \mathrm{mg} . / \mathrm{ml} .:$ glycine, L-glutamic acid, L-aspartic acid, L-valine, L-leucine, L-isoleucine, L-arginine, L-proline, L-alanine, L-histidine, L-lysine, L-tyrosine, L-cysteine, DL-threonine, DL- ornithine, DL-tryptophan and DL-phenylalanine. Organisms were added to a final concentration equiv. to $\mathbf{0 . 2} \mathrm{mg}$. dry wt. $/ \mathrm{ml}$; $100 \mathrm{ml}$. medium was incubated at $37^{\circ}$, in shaken flasks to improve aeration.

Bacterial growth was estimated from the optical density of the suspension by using a calibration curve as described above.

Flagellar regeneration was determined as follows, $(a)$ Motility determinations on $0.2 \mathrm{ml}$. samples added to $1.8 \mathrm{ml}$. nutrient broth containing $10 \mu \mathrm{g}$. chloramphenicol $/ \mathrm{ml}$. At this concentration chloramphenicol prevented the synthesis of flagella but had no effect on the motility of the organisms. The $\%$ organisms with translational motility was determined microscopically. (b) Flagellar staining. The bacterial flagella were stained by Leifson's (1951) method as modified by Quadling (1958). The mean number of flagella/bacterium and the $\%$ flagellated bacteria were determined.

Nucleic acid and protein synthesis. The fractionation procedure was based on that of Roberts, Cowie, Abelson, Bolton \& Britten (1955). The organisms in $10 \mathrm{ml}$. samples were harvested by centrifugation, resuspended in $3 \mathrm{ml}$. $5 \%(\mathrm{w} / \mathrm{v})$ trichloroacetic acid (TCA) and held at $4^{\circ}$ for $2 \mathrm{hr}$. The precipitate was harvested by centrifugation and after washing once with $5 \%(w / v)$ TCA was extracted for $30 \mathrm{~min}$. at $45^{\circ}$ in $3 \mathrm{ml} .75 \%(\mathrm{v} / \mathrm{v})$ ethanol in water. The suspension was centrifuged, the precipitate extracted for $30 \mathrm{~min}$. at $45^{\circ}$ in $2 \mathrm{ml} .75 \%(\mathrm{v} / \mathrm{v})$ ethanol in water $+2 \mathrm{ml}$. ether. The ethanol and ethanol + ether extracts were combined and after the addition of $5 \mathrm{ml}$. water were extracted three times with $5 \mathrm{ml}$. ether to remove the lipid fraction, which was discarded. The aqueous layer containing the ethanol-soluble protein was taken to dryness on a boiling water bath; the ethanol-soluble protein was then redissolved in $0.5 \mathrm{ml} . \mathrm{N}-\mathrm{NaOH}$ and estimated colorimetrically with Folin's reagent by the method of Lowry, Roseborough, Farr \& Randall (1951). The nucleic acid was extracted from the residue of the ethanol + ether extract with perchloric acid; two $20 \mathrm{~min}$. extractions at $70^{\circ}$ with $2 \mathrm{ml} .0 .5 \mathrm{~N}$-perchloric acid were sufficient to remove all the nucleic acid. The supernatant fluids from these two extractions were combined and made up to $5 \mathrm{ml}$. with $0.5 \mathrm{~N}$-perchloric acid. In certain experiments the nucleic acid was separated into the RNA and DNA fractions by the method of Ogur \& Rosen (1950). Total nucleic acid was determined after suitable dilution by estimating the optical density at $260 \mathrm{~m} \mu$ with a Unicam SP 500 spectrophotometer. DNA was determined by the diphenylamine method of Burton (1956) and RNA by the orcinol method of Morse \& Carter (1949). The residue after the extraction of nucleic acid was taken up in $5.0 \mathrm{ml} . \mathrm{N}-\mathrm{NaOH}$ and the protein content estimated colorimetrically with Folin's reagent (Lowry et al. 1951). 
Induction and estimation of nitratase activity in washed suspensions of Salmonella typhimurium. The induction was carried out anaerobically in Thunberg tubes at $37^{\circ}$ in a system consisting of: $0.05 \mathrm{M}$-phosphate buffer $(\mathrm{pH} \mathrm{7.0)}$; $0.01 \mathrm{M}-\mathrm{KNO}_{3}$; amino acid mixture as for the regeneration of flagella; $2.0 \%$ $(\mathrm{w} / \mathrm{v})$ glucose; organisms corresponding to a final concentration equiv. to $0.4 \mathrm{mg}$. dry wt./ml. After incubation for $2 \mathrm{hr}$. the organisms were harvested by centrifugation, washed once with distilled water, suspended in distilled water, and the concentration determined turbidimetrically. The nitratase activity was determined by the method of Pollock (1946).

\section{RESULTS \\ Conditions for flagellar regeneration.}

Both the degree of flagellation and the ability of suspensions of Salmonella typhimurium to regenerate their flagella after mechanical removal were found to depend on the conditions under which the organisms were grown. Flagellin can account for up to $1 \%$ of the dry weight of the organisms grown in nutrient broth when there are 4-5 flagella/bacterium. Organisms grown in the minimal medium, however, have fewer flagella/bacterium, and after mechanical removal their flagella do not regenerate as well as those of organisms grown in nutrient broth. Although it would have been more satisfactory to use organisms grown in a chemically defined medium, in view of their relative inability to regenerate their flagella, $S$. typhimurium grown in a nutrient broth was used.

The ability of different nitrogen sources to promote flagellar regeneration by the nutritionally non-exacting strain LT2 of Salmonella typhimurium in a chemically defined medium was studied. The nitrogen sources included ammonium salts, single amino acids and a complete mixture of amino acids. Only the complete mixture of amino acids gave consistently reproducible results as good as those obtained with organisms incubated in nutrient broth after the mechanical removal of their flagella. The addition of a purine and pyrimidine mixture (xanthine, hypoxanthine, adenine, guanine, thymine, uracil) in a concentration of $10 \mu \mathrm{g}$. each base $/ \mathrm{ml}$. had little or no effect on regeneration and was therefore not used routinely. Bacterial growth and the regeneration of flagella by the nutritionally non-exacting strain LT 2 of $S$. typhimurium in the chemically defined media are shown in Table 2. Regeneration occurred rapidly in this medium and after $1 \mathrm{hr}$. nearly all the organisms had regained their motility. The difference between the \% motile organisms (20$30 \%$ ) and \% flagellated organisms (90-93\%) after $30 \mathrm{~min}$. incubation was due to the fact that for the determination of $\%$ flagellated bacteria, every bacterium possessing one or more flagella (irrespective of length) was scored as flagellated, whereas a flagellum has to be a certain minimum length before the organisms become motile. Organisms in buffer alone showed no change in optical density and were unable to regenerate their flagella. The average number of flagella/bacterium after regeneration was always less than in the original culture. Concomitantly with the regeneration of flagella by strain 
LT2 the synthesis of nucleic acid and protein was estimated. The results of a typical experiment are shown in Table 3, in which the values for the ethanolsoluble protein and the residual protein are combined. Growth occurred, in all cases except in phosphate buffer, and there was a good correlation between the ability to regenerate flagella and to synthesize nucleic acid and protein.

Table 2. The effect of purines and pyrimidines on growth and flagellar regeneration of Salmonella typhimurium strain LT 2

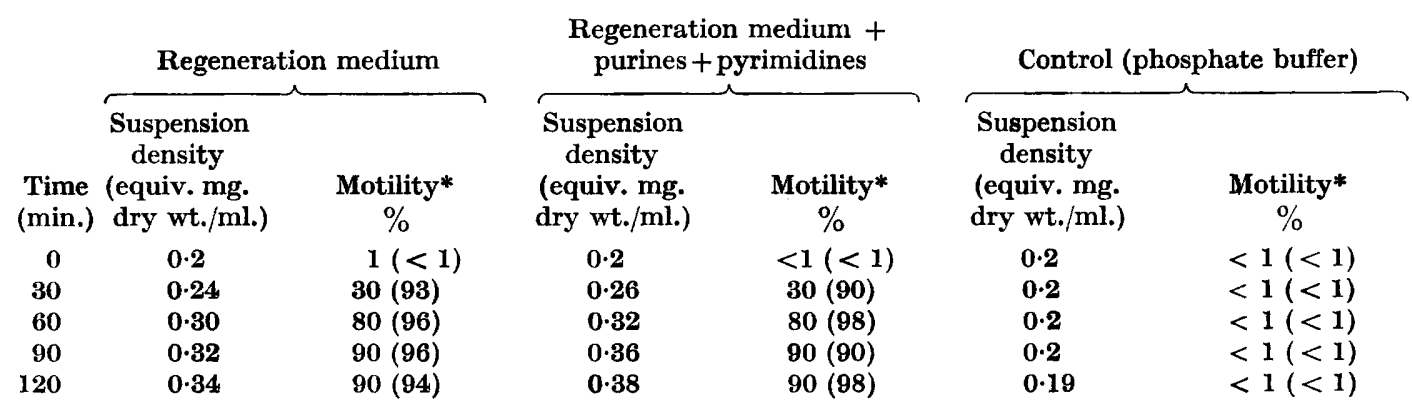

* The figures in parentheses are \% of flagellated bacteria determined in stained preparations.

Table 3. The effect of purines and pyrimidines on nucleic acid and protein synthesis by Salmonella typhimurium strain LT 2

\begin{tabular}{|c|c|c|c|c|c|c|c|c|c|}
\hline \multirow[b]{2}{*}{ Time (min.) } & \multicolumn{3}{|c|}{ Regeneration medium } & \multicolumn{3}{|c|}{$\begin{array}{c}\text { Regeneration medium }+ \\
\text { purines }+ \text { pyrimidines }\end{array}$} & \multicolumn{3}{|c|}{$\begin{array}{c}\text { Control } \\
\text { (phosphate buffer) }\end{array}$} \\
\hline & RNA* & DNA* & Proteint & RNA* & DNA* & Protein $\dagger$ & RNA* & DNA* & Protein $\dagger$ \\
\hline $\mathbf{0}$ & 347 & 74 & 149 & 347 & 74 & 149 & 347 & 74 & 149 \\
\hline 30 & 388 & 87 & 168 & 425 & 99 & 176 & 338 & 74 & 151 \\
\hline 60 & 462 & 105 & 197 & 485 & 115 & 223 & - & 77 & 157 \\
\hline 90 & 513 & 128 & 242 & 567 & 130 & 264 & 342 & 70 & 159 \\
\hline 120 & 580 & 155 & 255 & 542 & 150 & 278 & 368 & 63 & 165 \\
\hline
\end{tabular}

\section{Flagellar synthesis by amino acid-requiring mutants of Salmonella typhimurium}

The amino acid-requiring mutants examined for their ability to regenerate flagella can be divided into two major groups $a$ and $b$ and one intermediate group $c$.

(a) Mutants requiring an amino acid present in flagellin; unable to regenerate flagella in the absence of the amino acid required for growth

Glutamic acid, leucine and tyrosine are all present in the flagellin of Salmonella typhimurium and one strain exacting for each of these amino acids was tested. All strains grew and synthesized flagella in the complete regeneration medium (Table 4), although the recovery of motility after incubation for $2 \mathrm{hr}$. was not as good as in the nutritionally non-exacting strain LT2. When the amino acid required for growth was omitted from the medium there was 
Table 4. The effect of essential amino acid nutrients on growth and flagellar regeneration by amino acid-requiring strains of Salmonella typhimurium

\begin{tabular}{|c|c|c|c|c|c|}
\hline \multicolumn{2}{|c|}{ Regeneration medium } & \multicolumn{2}{|c|}{$\begin{array}{l}\text { Regeneration medium } \\
\text { lacking growth } \\
\text { requirement }\end{array}$} & \multicolumn{2}{|c|}{$\begin{array}{c}\text { Control } \\
\text { (phosphate buffer }+ \\
\text { glucose) }\end{array}$} \\
\hline $\begin{array}{c}\text { Suspension } \\
\text { optical } \\
\text { density } \\
\% \\
\% \\
\text { increase }\end{array}$ & $\begin{array}{c}\text { Motility* } \\
(\%)\end{array}$ & $\begin{array}{c}\text { Suspension } \\
\text { optical } \\
\text { density } \\
\% \\
\text { increase }\end{array}$ & $\begin{array}{c}\text { Motility* } \\
(\%)\end{array}$ & $\begin{array}{c}\text { Suspension } \\
\text { optical } \\
\text { density } \\
\% \\
\text { increase }\end{array}$ & $\begin{array}{c}\text { Motility } \\
(\%)\end{array}$ \\
\hline 35 & $40(50)$ & 7 & $<1(1)$ & 0 & $<1$ \\
\hline 65 & $10(60)$ & 13 & $<1(<1)$ & ) -1 & \\
\hline 78 & $50(40)$ & -3 & $<1(<1)$ & 0 & $<1$ \\
\hline 90 & 20 & -13 & $<1$ & -15 & $<1$ \\
\hline 60 & $40(39)$ & 16 & $50(35)$ & -7 & $<1$ \\
\hline 45 & $70(90)$ & 2 & $65(85)$ & -12 & $<1$ \\
\hline 78 & 80 & $-\overline{1}$ & 50 & -1 & $<1$ \\
\hline 66 & 70 & -1 & 30 & -17 & 10 \\
\hline 106 & 80 & -12 & 10 & -13 & 2 \\
\hline 100 & 70 & 6 & 40 & -15 & 5 \\
\hline 120 & 70 & -6 & 40 & 2 & 2 \\
\hline 110 & 80 & 6 & 40 & -6 & 10 \\
\hline 110 & 70 & 6 & 40 & -8 & 5 \\
\hline 55 & 70 & 3 & 60 & -9 & $<1$ \\
\hline 92 & 80 & -6 & 40 & -6 & 10 \\
\hline 76 & 60 & 13 & 10 & -10 & $<1$ \\
\hline
\end{tabular}

* The figures in parentheses are \% flagellated bacteria in stained preparations.

Table 5. The effect of essential nutrient amino acids on nucleic acid and protein synthesis by amino acid-requiring strains of Salmonella typhimurium

$\%$ increase after aerobic incubation for $2 \mathrm{hr}$. at $37^{\circ}$

\begin{tabular}{|c|c|c|c|c|c|c|c|c|c|c|c|}
\hline \multirow[b]{2}{*}{ Strain } & \multirow[b]{2}{*}{$\begin{array}{c}\text { Growth } \\
\text { requirement }\end{array}$} & \multirow{2}{*}{$\begin{array}{l}\text { Starva- } \\
\text { tion }\end{array}$} & \multicolumn{3}{|c|}{ Regeneration medium } & \multicolumn{3}{|c|}{$\begin{array}{l}\text { Regeneration medium } \\
\text { lacking growth } \\
\text { requirement }\end{array}$} & \multicolumn{3}{|c|}{$\begin{array}{c}\text { Control } \\
\text { (phosphate buffer }+ \\
\text { glucose) }\end{array}$} \\
\hline & & & RNA & DNA & Protein & RNA & DNA & Protein & RNA & DNA & Protein \\
\hline \multicolumn{12}{|l|}{ Group a } \\
\hline SL 185 & Leucine & - & 40 & 150 & 47 & -2 & 100 & 2 & 17 & -7 & -1 \\
\hline SL 185 & Leucine & + & 10 & $\mathbf{5 5}$ & 38 & -8 & 17 & $-\mathbf{3}$ & $-\gamma$ & 8 & 5 \\
\hline SL 186 & Tyrosine & . & 38 & 108 & 102 & -1 & 77 & -2 & $-\mathbf{2 1}$ & 10 & 3 \\
\hline SL 443 & Glutamic & . & 63 & 114 & 98 & -10 & 26 & -12 & -18 & 23 & $\mathbf{0}$ \\
\hline \multicolumn{12}{|l|}{ Group b } \\
\hline SL 291 & Cysteine & . & 42 & 100 & 61 & -5 & 60 & 3 & -14 & $\mathbf{0}$ & -6 \\
\hline SL 282 & Tryptophan & . & 25 & 113 & 54 & o & 107 & 4 & 0 & 3 & 6 \\
\hline SL 282 & Tryptophan & + & 60 & 170 & 110 & -3 & 43 & 9 & -10 & 45 & 2 \\
\hline \multicolumn{12}{|l|}{ Group c } \\
\hline SL 262 & Methionine & . & 30 & 94 & 40 & -16 & 33 & -10 & -23 & -4 & -4 \\
\hline SL 286 & Histidine & . & 13 & 53 & 23 & 6 & 40 & 1 & 4 & -4 & -4 \\
\hline
\end{tabular}


little change in the optical density of the corresponding nutritionally exacting mutants and the organisms did not recover their motility; i.e. they were unable to regenerate their flagella (Table 4). The most noticeable feature is that although net RNA and protein synthesis did not occur (the small changes are within the limits of the experimental error) in the presence of a source of energy and of nitrogen but in the absence of the specific amino acid required for growth, the organisms were still capable of synthesizing DNA (Table 5). The results are similar to those obtained with Escherichia coli mutants by Pardee \& Prestridge (1956).

(b) Mutants requiring for growth an amino acid absent from flagellin and able to regenerate flagella in the absence of their growth requirement.

The amino acids tryptophan, cysteine and hydroxyproline are not present in the flagellin of Salmonella typhimurium. Growth and flagellar regeneration were followed in a cysteine-requiring mutant (SL 291) and in a tryptophanrequiring mutant (SL 282) of $S$. typhimurium (Table 4). There was very good regeneration of flagella by the tryptophan-requiring mutant in the presence and in the absence of tryptophan. Previous starvation of the organisms had little effect on regeneration. There was little or no change in the optical density of a suspension of strain SL 282 during incubation for $2 \mathrm{hr}$. in medium which lacked tryptophan. The cysteine-requiring mutant behaved similarly except that its recovery of motility even in the presence of cysteine was poorer than that of the tryptophan-requiring mutant (Table 4). Although there was a $16 \%$ increase in the optical density of a suspension of strain SL 291 in a medium lacking cysteine, there was no accompanying change in the protein content (Table 5). Both the tryptophan- and cysteine-requiring mutants behaved like the other mutants in respect of nucleic acid and protein synthesis in the regeneration medium, with or without their amino acid growth requirement (Table 5). The addition of tryptophan to a suspension of strain SL 282 in regeneration medium lacking tryptophan resulted in the immediate synthesis of RNA and protein; synthesis of DNA continued at the same rate as before (Fig. 1).

As a further check on the results about nucleic acid synthesis by the amino acid-requiring mutants of Salmonella typhimurium the nucleic acid was fractionated into the RNA and DNA components at the end of a regeneration test of strain SL 282 (tryptophan-requiring). The results (Table 6) are consistent with those obtained in the earlier experiments. There was little or no RNA synthesis in the absence of the amino acid required for growth, but there was considerable synthesis of DNA.

(c) Mutants which require for growth an amino acid present in flagellin, but which are able to regenerate flagella in the absence of this amino acid

The mutants examined in this group were histidine- and methionine-requiring strains of Salmonella typhimurium. A fairly high proportion of organisms in a deflagellated suspension regenerated their flagella in a medium which lacked the amino acid required for growth (Table 4) although the amino 
acids required for growth are present in flagellin. The histidine-requiring strains were typical of these organisms. Strain SL 286 was first examined; because of the rather unexpected results obtained mutants blocked at other histidine loci were also tested (Tables 1 and 4). All the histidine-requiring strains of $S$. typhimurium regenerated their flagella readily in complete

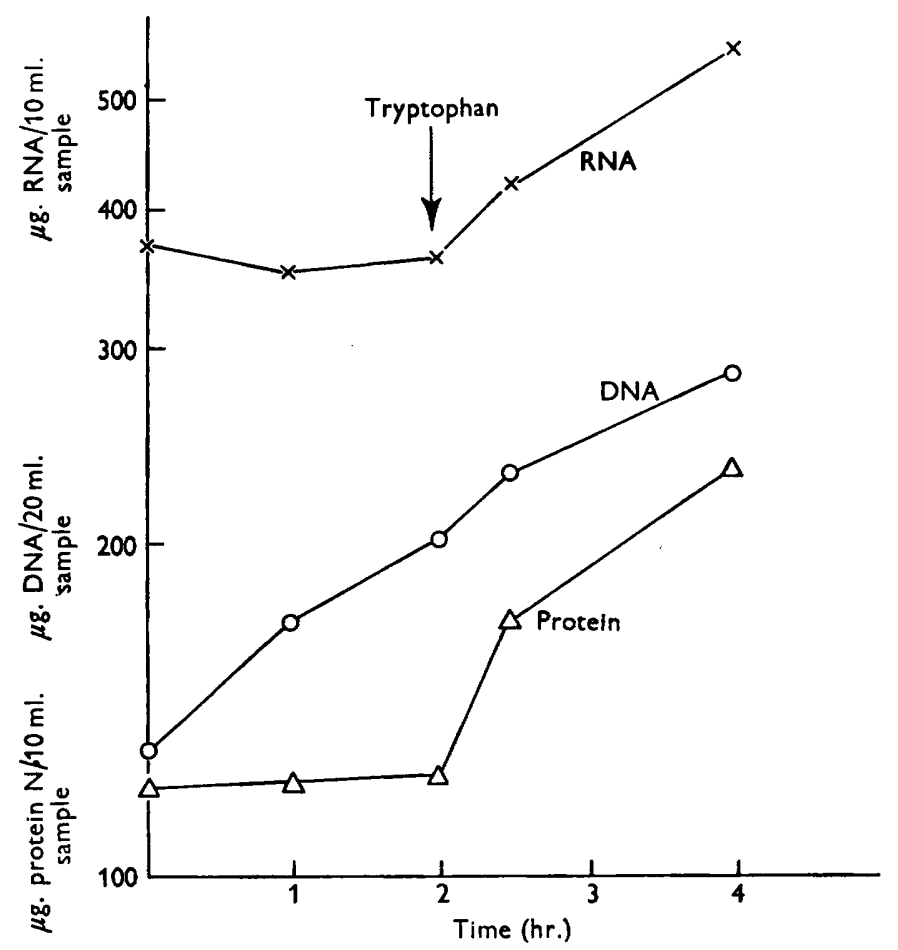

Fig. 1. The effect of the addition of tryptophan on nucleic acid and protein synthesis by Salmonella typhimurium, strain SL 282 (tryptophan-requiring).

Table 6. The effect of tryptophan on the synthesis of RNA and DNA by the tryptophan-requiring strain SL 282 of Salmonella typhimurium

\begin{tabular}{|c|c|c|c|c|c|c|}
\hline \multirow[b]{3}{*}{ Method of estimation } & \multicolumn{6}{|c|}{$\%$ increase after aerobic incubation for $2 \mathrm{hr}$. at $37^{\circ}$} \\
\hline & \multicolumn{2}{|c|}{ Regeneration medium } & \multicolumn{2}{|c|}{$\begin{array}{l}\text { Regeneration medium } \\
\text { lacking tryptophan }\end{array}$} & \multicolumn{2}{|c|}{$\begin{array}{c}\text { Control } \\
\text { (phosphate buffer + glucose }\end{array}$} \\
\hline & RNA & DNA & RNA & DNA & RNA & DNÁ \\
\hline Diphenylamine & - & 110 & - & 53 & - & 8 \\
\hline $\log I_{o} / I$ at $260 \mathrm{~m} \mu$ & 60 & 120 & -2 & 51 & -10 & $\mathbf{5}$ \\
\hline
\end{tabular}

medium; at least $70 \%$ of the organisms were motile after incubation for $2 \mathrm{hr}$. Starvation of the suspensions in a chemically defined medium which lacked histidine, before regeneration in complete medium, had no effect on the regeneration of flagella. In medium lacking histidine there was a moderately good recovery of motility, varying from 30 to $60 \%$ in the non-starved suspension 
and from 10 to $40 \%$ in the starved suspension, although the optical density changed little during the $2 \mathrm{hr}$. period. When the histidine-requiring strains were incubated in the absence of a nitrogen source there was a small recovery of motility but in no case did this exceed the recovery by organisms incubated in medium lacking histidine. The methionine-requiring mutant of $S$. typhimurium (SL 262) behaved like the histidine-requiring strains, although the recovery of motility in the absence of the amino acid required for growth was not good. The synthesis of nucleic acid and protein by strain SL 262 (methionine-requiring) and strain SL 286 (histidine-requiring) was similar to that by the other amino acid-requiring strains of $S$. typhimurium.

\section{Nitratase synthesis by amino acid-requiring mutants of Salmonella typhimurium}

The ability of amino acid-requiring mutants of Salmonella typhimurium to synthesize protein in the absence of their growth requirement was examined by studying the synthesis of the adaptive (inducible) nitratase system in strain SL 282 (tryptophan-requiring) and strain SL 443 (glutamic acidrequiring). The increase in nitratase activity was inhibited by growthinhibitory concentrations of chloramphenicol; this presumably resulted from

Table 7. The effect of various substances on the synthesis of nitratase by amino acid-requiring strains of Salmonella typhimurium

\begin{tabular}{|c|c|c|c|c|c|c|c|}
\hline & Ad & tions to $\mathrm{tl}$ & le basal ada & ptation medi & um & & \\
\hline & $\begin{array}{l}\text { Glutamic } \\
\text { acid }\end{array}$ & $\begin{array}{c}\text { Trypto- } \\
\text { phan }\end{array}$ & $\begin{array}{c}\text { Purine and } \\
\text { pyrimidine } \\
\text { mixture } \\
(10 \mu \mathrm{g} . \text { of }\end{array}$ & Chloram- & & $\begin{array}{r}\text { Nitrat } \\
(\mu \text { mole N }\end{array}$ & $\begin{array}{l}\text { tivity } \\
\text {./hr.) }\end{array}$ \\
\hline Strain & ml.) & ml.) & ml.) & $(10 \mu \mathrm{g} . / \mathrm{ml})$. & $(0.01 \mathrm{M})$ & Initial & Final \\
\hline SL 282. Tryptophan- & + & + & + & - & - & 1.75 & $1 \cdot 69$ \\
\hline requiring & + & + & + & + & + & $1 \cdot 75$ & $\mathbf{2} \cdot 12$ \\
\hline & + & + & + & - & + & 1.75 & $8 \cdot 74$ \\
\hline & + & + & - & - & + & 1.75 & $8 \cdot 76$ \\
\hline & + & - & + & - & + & 1.75 & $1 \cdot 64$ \\
\hline & + & - & - & - & + & $1 \cdot 75$ & 1.72 \\
\hline SL443. Glutamic & + & + & + & - & - & $1 \cdot 33$ & 0.91 \\
\hline acid requiring & + & + & + & + & + & 1.33 & $1 \cdot 33$ \\
\hline & + & + & + & - & + & $\mathbf{1 . 3 3}$ & $6 \cdot 5$ \\
\hline & + & + & - & - & + & 1.33 & $4 \cdot 6$ \\
\hline & - & + & + & - & + & 1.33 & 1.02 \\
\hline & - & + & - & - & + & $\mathbf{1} \cdot \mathbf{3 3}$ & $1 \cdot 43$ \\
\hline
\end{tabular}

an inhibition of protein synthesis. When organisms of either strain were incubated in the complete adaptation medium there was an approximate five-fold increase in the nitratase activity during the $2 \mathrm{hr}$. anaerobic incubation. When, however, the amino acid required for growth was omitted from the amino acid mixture there was little or no change in the nitratase activity of the suspensions. Thus, in the absence of the amino acid required for growth the two auxotrophic mutants did not synthesize nitratase (Table 7). 


\section{DISCUSSION}

Adaptive enzyme formation by washed suspensions of bacteria was first used to study the formation of individual proteins; later Monod and his collaborators studied the differential synthesis of enzymes in logarithmically growing cultures of Escherichia coli (see Cohn, 1957). In both these approaches, although the synthesis of only one protein is followed, other proteins are also being synthesized. It was with the idea of overcoming this limitation that the study of the synthesis of flagella by amino acid-requiring mutants of Salmonella typhimurium was begun. Flagella are ideal as a single protein for synthetic studies because they consist only of protein and constitute up to $1 \%$ of the dry weight of the organisms. This protein is well characterized serologically and chemically and is easily isolated and purified. A further advantage of this system is the possibility of studying the behaviour of individual bacteria within the population. The system has a major disadvantage in that although qualitative estimation of flagellar synthesis is easy, quantitative estimation is difficult.

When the amino acid-requiring mutants were incubated in the regeneration medium from which the amino acid required for growth had been omitted, there was little or no net synthesis of RNA or protein, but DNA was synthesized. The results are similar to those of Pardee \& Prestridge (1956) who used auxotrophic mutants of Escherichia coli. Although increases in RNA and protein were not detected when the salmonella strains were incubated in the absence of their growth requirement, certain strains regenerated their flagella under these conditions. The behaviour of the glutamic acid-, leucine- and tyrosine-requiring strains (group a) and the tryptophan- and cysteine-requiring strains (group b) is to be expected since it is plausible to assume that in the absence of their amino acid growth requirement, strains which require an amino acid for growth would synthesize proteins which lacked that amino acid but not proteins which contained it. The behaviour of the histidinerequiring mutants and the methionine-requiring mutant (group c) is difficult to reconcile with that of the mutants in group a. Histidine and methionine occur to a limited extent in flagellin (approximately 3 mole $/ 10^{5} \mathrm{~g}$. compared to $78 \mathrm{~mole} / 10^{5} \mathrm{~g}$. for leucine and $21 \mathrm{~mole} / 10^{5} \mathrm{~g}$. for tyrosine) and although the synthesis of flagellin might be accounted for by the presence of these amino acids in an amino acid pool, the ability of starved preparations to regenerate flagella in the absence of their amino acid growth requirement makes this unlikely. The demonstration of protein turnover in resting suspensions of E. coli (Mandelstam, 1958) suggests an explanation. If one assumes a similar turnover in Salmonella typhimurium then a limited amount of histidine and methionine would be available for the synthesis of protein and the relative amount of a particular protein synthesized would depend on the number of histidine or methionine residues/ protein molecule. Flagellin would be at an advantage in that it contains only one histidine and one methionine residue/ flagellin molecule of mol. wt. 30,000. Consequently the synthesis of flagellin would be more probable than that of other proteins containing more histidine 
or methionine residues/protein molecule. The failure to show synthesis of RNA associated with the regeneration of flagella by the amino acid-requiring mutants when incubated in the absence of the amino acid required for growth was no doubt due to the insensitivity of the estimation procedures used. Any increase in RNA occurring during the synthesis of flagella by amino acidrequiring mutants in the absence of their growth requirement would be less than $1 \%$; this increase would not be detected by the methods used to estimate RNA.

The ability to regenerate flagella is not constant among the individuals of a bacterial population. Some organisms do not regenerate flagella during the period of the test and the proportion of these varies from strain to strain. Different organisms are probably in different phases of division when harvested and the synthesis of flagella might occur only during particular periods of this cycle. This explanation would be in accord with the results of Lark \& Maaløe (1956) on the synthesis of nucleic acid and protein by synchronously dividing cultures of Salmonella typhimurium.

\section{REFERENCES}

Burton, K. (1956). A study of the conditions and mechanism of the diphenylamine reaction for the colorimetric estimation of deoxyribonucleic acid. Biochem. J. 62, 315.

CoHs, M. (1957). Contributions of the studies on the $\beta$-galactosidase of Escherichia coli to our understanding of enzyme synthesis. Bact. Rev. 21, 140.

Demerec, M., Hartman, Z., Hartman, P. E., Yura, T., Demerec, Z. E., Gots, J. S., Ozeki, H. \& Glover, S. W. (1956), Genetic studies with bacteria. Publ. Carneg. Instn, no. 612.

Fox, E. N. \& Krampitz, L. O. (1956). Studies on the biosynthesis of the M protein of group A haemolytic streptococci. J. Bact. 71, 454 .

LARK, K. G. \& MAALøE, O. (1956). Nucleic acid and the division cycle of Salmonella typhimurium. Biochim. Biophys. Acta, 21, 448.

LeIfson, E. (1951). Staining, shape and arrangement of bacterial flagella. J. Bact. $62,377$.

Lowry, O. H., Rosebrough, N. J., Farr, A. L. \& Randald, R. J. (1951). Protein estimation with the folin phenol reagent. J. biol. Chem. 192, 265.

MandelstaM, J. (1958). Turnover of protein in growing and non-growing populations of Escherichia coli. Biochem. J. 69, 110.

Morse, M. L. \& CARTER, C. E. (1949). The synthesis of nucleic acids in cultures of Escherichia coli strains B and B/R. J. Bact. 58, 317.

Ogur, M. \& Rosen, G. (1950). The nucleic acids of plant tissues. 1. The extraction and estimation of RNA and DNA. Arch. Biochem. Biophys. 25, 262.

Pardee, A. B. \& Prestridge, L. S. (1956). The dependence of nucleic acid synthesis on the presence of amino-acids in Escherichia coli. J. Bact. 71, 677.

Pollock, M. R. (1946). Adaptation of 'nitratase' in washed suspensions of bacteria. Brit. J. exp. Path. 27, 419.

QuADLING, C. (1958). The unilinear transmission of motility and its material basis in Salmonella. J. gen. Microbiol. 18, 237.

Rinker, J. N., Kobayashi, T. \& Koffler, H. (1957). Isolation and chemical properties of flagellar proteins. Fed. Proc. 16, 238. 
Roberts, R. B., Cowie, D. B., Abelson, P. H., Bolton, E. T. \& Britten, R. J. (1955). Studies of biosynthesis in Escherichia coli. Publ. Carneg. Instn, no. 607 .

STocker, B. A. D. (1957). Methods of removing flagella from live bacteria; effects on motility. J. Path. Bact. 73, 314.

Weibull, C. (1953). The free amino-groups of the Proteus flagellar protein. Quantitative determinations of the DNP amino-acids using paper chromatography. Acta Chem. Scand. 7, 233.

Zinder, N. D. \& Lederberg, J. (1952). Genetic exchange in Salmonella. J. Bact. 64, 679 .

(Received 27 January 1959) 